\title{
Structural Modifications on Natural-based Products: Synthetic Strategies and Biological Applications
}

\author{
André Fonseca $^{\mathrm{a}, b^{*}}$, Maria João Matos ${ }^{\mathrm{a}, \mathrm{b}}$, Saleta Vazquez-Rodriguez ${ }^{\mathrm{a}, \mathrm{b}}$, Dolores Viña ${ }^{\mathrm{c}}$, Santiago \\ Vilar $^{\mathrm{b}, \mathrm{d}}$, Fernanda Borges ${ }^{\mathrm{a}}$, Lourdes Santana ${ }^{\mathrm{b}}$ and Eugenio Uriarte ${ }^{\mathrm{b}}$ \\ ${ }^{a}$ CIQUP/Departamento de Química e Bioquímica, Faculdade de Ciências, Universidade do Porto, 4169-007 Porto, \\ Portugal \\ ${ }^{\text {b }}$ Departamento de Química Orgánica, Facultad de Farmacia, Universidad de Santiago de Compostela, 15782 \\ Santiago de Compostela, Spain \\ ${ }^{c}$ Departmento de Farmacologia, CIMUS, Universidad de Santiago de Compostela, 15782 Santiago de Compostela, \\ Spain \\ ${ }^{\mathrm{d}}$ Department of Biomedical Informatics, Columbia University Medical Center, 10032 New York, USA
}

*andrefonsecaa12@gmail.com

\begin{abstract}
Coumarins are a class of heterocyclic compounds present in a significant quantity in several plants. The simplest coumarin, a benzene ring fused with a pyran-2one heterocycle, was first discovered in the $19^{\text {th }}$ century and since then, due to the synthetic accessibility and the biological properties of its derivatives, has been playing an important role in the Medicinal Chemistry field. In fact, coumarins have been previously described as anticancer, antiviral, anti-inflammatory, antimicrobial, enzymatic inhibitory and antioxidant agents.

Another two interesting compounds found widely in nature are resveratrol derivatives and chalcones. Both families of compounds are known for having remarkable antioxidant activity, cardio- and neuroprotective effects, among other relevant biological properties. Therefore, we devised several synthetic strategies to incorporate these natural products in one compound, combining their potential as promising agents for the treatment of several illnesses.

In our group, we have already synthesised multiple novel compounds incorporating into the coumarin scaffold the resveratrol or chalcones moieties with remarkable activities towards different pharmacological targets. In this work, we continue exploiting this strategy by incorporating different linkers at coumarin position 3, thus giving us a wide range of possibilities for new compounds.
\end{abstract}

Keywords: Natural products, coumarins, resveratrol, chalcones, pharmacological applications. 


\section{Introduction}

Before modern medicine, extracts of plants or plants itself were consumed for their medicinal properties in spite of lack of knowledge of its components or active compound. Nevertheless, we always relied on natural sources to cure ailments and diseases, and the study of natural extracts yielded a vast number of commercial available drugs, just by isolating a pharmacologically active compound or by synthesising an active compound through inspiration of a natural product structure. ${ }^{[1]}$ Today we are facing changing demographics, the extension of life expansion lead to a growing number of cases of neurodegenerative diseases. Thus, there is always a need for a new drug that is safe and can ameliorate the symptoms or even treat these diseases. Three major classes of products found in nature and with great pharmacological interest are the coumarins, chalcones and the resveratrol derivatives. Coumarins and their natural and/or synthetic derivatives are pharmacologically interesting compounds due to their structural diversity, synthetic accessibility and substitution variability. ${ }^{[1,2]}$ These heterocyclic compounds have already been previously described as anticancer, antiviral, anti-inflammatory, antimicrobial, enzymatic inhibitory and antioxidant agents. ${ }^{[3-18]}$ Taking in account the versatility of the coumarin moiety one can thoroughly modify it to best serve one purposes. In this work, our group fused two other classes of natural products onto the coumarin skeleton, the chalcones (figure 1 - A) and the resveratrol derivatives (figure 1 - B). We further explored this nucleus by introducing linkers (figure 1 - C and D), giving us a wide variety of naturally inspired compounds.

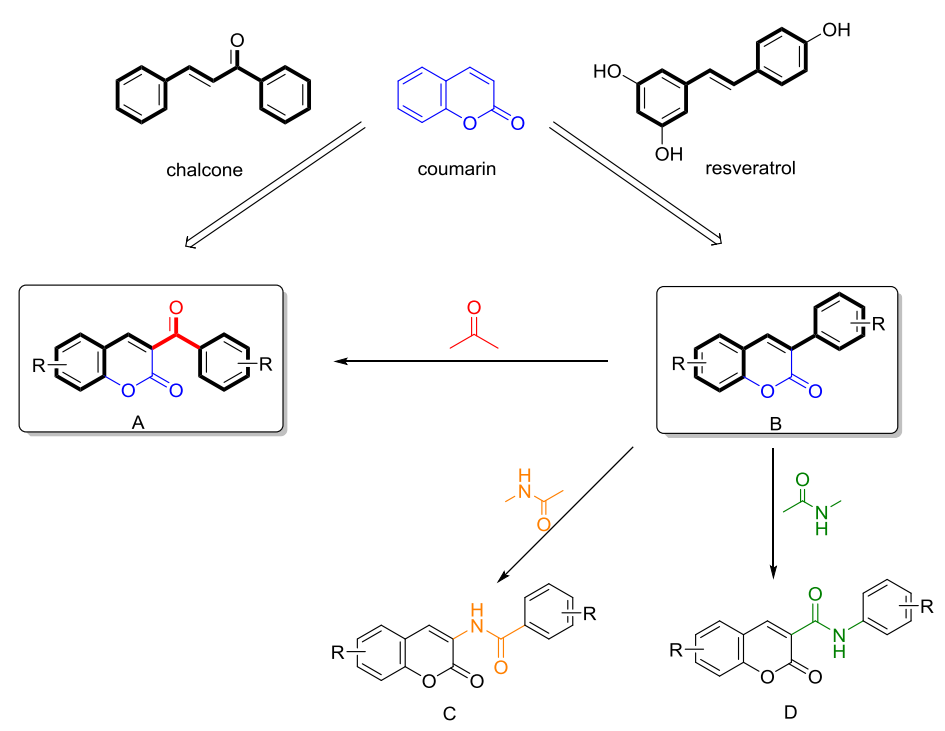

Figure 1 - Scheme of the different compound synthesized A - coumarin-chalcone hybrid, B - coumarin-resveratrol hybrid and its derivatives: C and D. By introducing a carbonyl group in B we can obtain A. 
Chalcones are widely spread in fruits, vegetables, edible plants, spices and tea and have been subject of study for their remarkable pharmacological activity. In addition, they are considered to be precursors of flavonoids and isoflavonoids. ${ }^{[19]}$ Resveratrol and its derivatives are present primarily in red wine, skin of red grapes and peanuts and present significant anti-oxidant activity.

Our goal is to combine the structure of these compounds with a coumarin skeleton to achieve new chemical entities with extraordinary activity towards different targets, mostly focusing on age related diseases. This way we conducted studies of acetylcholinesterase (AChE) and butyrylcholinesterase (BuChE) inhibition, proven their involvement in the progression of Alzheimer's disease, monoamine oxidase A (MAOA) and B (MAO-B) inhibition for their importance as targets for treating Parkinson's, anti-oxidant activity and cytotoxicity. The series of compounds synthesized are shown in figure $2-\mathrm{A}, \mathrm{B}$ and $\mathrm{C}$.

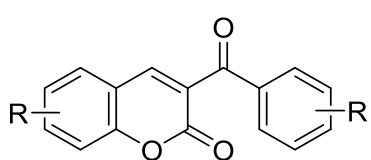

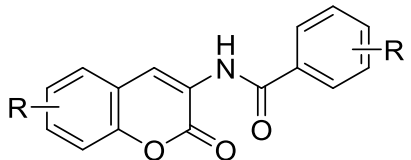

B

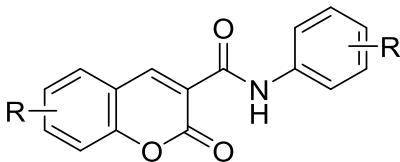

C

Figure 2 - Classes of compound synthesized: A - Coumarin-chalcones derivatives; B and C - 3-amidocoumarins.

All together our group synthesized a total of 16 compounds and performed various assays like mentioned before.

\section{Experimental}

\section{Chemistry}

The chemicals used in the synthesis were supplied by Aldrich and Merck. Melting points were determined using a Reichert Kofler thermopan or in capillary tubes on a Büchi 510 apparatus and are uncorrected. ${ }^{1} \mathrm{H}$ NMR spectra were recorded on a Bruker AMX spectrometer at $250 \mathrm{MHz}$, using TMS as internal standard (chemical shifts in $\delta$ values, $J$ in $\mathrm{Hz}$ ). Silica gel (Merck 60, 230-00 mesh) was used for flash chromatography (FC). Analytical thin layer chromatography (TLC) was performed on plates precoated with silica gel (Merck 60 F254, $0.25 \mathrm{~mm}$ ). 


\section{General procedure for the preparation of coumarin-chalcone precursors $(1-4)^{[20]}$}

To a solution of $1 \mathrm{mmol}$ of the appropriate $\beta$-ketoester and $1 \mathrm{mmol}$ of the correspondent salicylaldehyde in ethanol $(\mathrm{EtOH})$, in a round bottom flask with a flux of argon at reflux, was added catalytic amounts of piperidine. The reaction mixture was then stirred for 2-5 h. After completion the obtained precipitate was filtered off, washed with cold $\mathrm{EtOH}$ and purified by recrystallization with dichloromethane/methanol mixture to give the desired product (scheme 1).

\section{General procedure for the preparation of hydroxylated coumarin-chalcone derivatives $(5-8)^{[20]}$}

To $1 \mathrm{mmol}$ of the corresponding methoxy-3-benzoylcoumarin, $\mathrm{BBr}_{3}$ in $\mathrm{DCM}$ (20 mmol, 1M) was added in a Schlenk tube. The tube was sealed, and the reaction mixture was heated at $80{ }^{\circ} \mathrm{C}$ for $48 \mathrm{~h}$. The resulting crude product was treated with $\mathrm{MeOH}$ and rotated to dryness. The obtained precipitate was recrystallized from $\mathrm{MeOH}$ or purified by flash chromatography using hexane/ethyl acetate mixtures as the eluent to afford the desired hydroxy derivative (scheme 1).<smiles>[R]c1cc([R1])c(O)c(C=O)c1</smiles>

$\mathrm{R}^{3}=\mathrm{H}, \mathrm{Br}$ $\mathrm{R}^{4}=\mathrm{H}, \mathrm{OMe}$<smiles>[R]c1ccc(C(=O)CC(=O)OCC)cc1[R]</smiles>

$\mathrm{R}^{1}=\mathrm{H}, \mathrm{OMe}$ $\mathrm{R}^{2}=\mathrm{H}, \mathrm{OMe}$

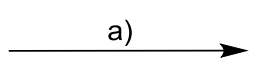

$1 \mathrm{R}^{1}=\mathrm{R}^{3}=\mathrm{R}^{4}=\mathrm{H} ; \mathrm{R}^{2}=\mathrm{OMe}$

$2 \mathrm{R}^{1}=\mathrm{R}^{2}=\mathrm{H} ; \mathrm{R}^{3}=\mathrm{Br} ; \mathrm{R}^{4}=\mathrm{OMe}$

$3 \mathrm{R}^{1}=\mathrm{R}^{2}=\mathrm{R}^{4}=\mathrm{OMe} ; \mathrm{R}^{3}=\mathrm{H}$

$4 \mathrm{R}^{1}=\mathrm{R}^{2}=\mathrm{R}^{4}=\mathrm{OMe} ; \mathrm{R}^{3}=\mathrm{Br}$

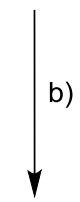

$$
\begin{array}{ll}
5 \mathrm{R}^{1}=\mathrm{R}^{3}=\mathrm{R}^{4}=\mathrm{H} ; \mathrm{R}^{2}=\mathrm{OH} \\
6 \mathrm{R}^{1}=\mathrm{R}^{2}=\mathrm{H} ; \mathrm{R}^{3}=\mathrm{Br} ; \mathrm{R}^{4}=\mathrm{OH} \\
7 \mathrm{R}^{1}=\mathrm{R}^{2}=\mathrm{R}^{4}=\mathrm{OH} ; \mathrm{R}^{3}=\mathrm{H} \\
8 \mathrm{R}^{1}=\mathrm{R}^{2}=\mathrm{R}^{4}=\mathrm{OH} ; \mathrm{R}^{3}=\mathrm{Br}
\end{array}
$$

Scheme 1 - Preparation of coumarin-chalcone derivatives. Reagents and conditions: a) piperidine, EtOH, reflux, 2-5h; b) $\mathrm{BBr}_{3}, 80^{\circ} \mathrm{C}, 48 \mathrm{~h}, \mathrm{DCM}$. 
General procedure for the preparation of the 3-amidocoumarin derivatives (9-12)

To a solution of $5 \mathrm{mmol}$ of coumarin-3-carboxylic acid in dichloromethane (DCM), in a round bottom flask with a flux of argon at $0{ }^{\circ} \mathrm{C}, 5.5 \mathrm{mmol}$ of 1-ethyl-3-(3dimethylaminopropyl)carbodiimide (EDC) and $5.5 \mathrm{mmol}$ of 4-dimethylaminopyridine (DMAP) were added. Short after was added, in small portions, $5 \mathrm{mmol}$ of the corresponding amine, and then the reaction mixture was stirred for $4 \mathrm{~h}$ at room temperature. The obtained precipitate was filtered and purified by recrystallization with ethanol or by column chromatography (hexane/ethyl acetate 9:1) to give the desired product (Scheme 2 - A).

\section{General procedure for the preparation of 3-amidocoumarin derivatives $(12-16)^{[21]}$}

To a solution of 3-aminocoumarin $(1 \mathrm{mmol})$ and pyridine $(1.1 \mathrm{mmol})$ in dichloromethane $(9 \mathrm{~mL})$, the corresponding acid chloride $(1.1 \mathrm{mmol})$ was added dropwise and the reaction was stirred, at room temperature, for 3 hours. The solvent was evaporated under vacuum and the dry residue was purified by FC (hexane/ethyl acetate 9:1) (Scheme 2 - B).

A.<smiles>O=C(O)c1cc2cc([14Cl])ccc2oc1=O</smiles>

a)<smiles>[R]c1ccc2oc(=O)c(C(=O)Nc3ccccc3)cc2c1</smiles>

$9 \mathrm{R}=\mathrm{H} ; \mathrm{R}^{1}=\mathrm{H}$

$10 \mathrm{R}=\mathrm{o}-\mathrm{OH} ; \mathrm{R}^{1}=\mathrm{H}$

$11 \mathrm{R}=m-\mathrm{OH} ; \mathrm{R}^{1}=\mathrm{H}$

$12 \mathrm{R}=\mathrm{o}-\mathrm{OH} ; \mathrm{R}^{1}=\mathrm{CH}_{3}$

B.<smiles>Nc1cc2ccccc2oc1=O</smiles>

b)<smiles>[R]c1ccc(C(=O)Nc2cc3ccccc3oc2=O)cc1[R]</smiles>

$13 \mathrm{R}=\mathrm{H} ; \mathrm{R}^{1}=\mathrm{H}$

$14 \mathrm{R}=\mathrm{OMe} ; \mathrm{R}^{1}=\mathrm{H}$

$15 \mathrm{R}=\mathrm{OMe} ; \mathrm{R}^{1}=\mathrm{OMe}$

$16 \mathrm{R}=\mathrm{Cl} ; \mathrm{R}^{1}=\mathrm{H}$

Scheme 2 - Reagents and conditions: a) EDC, DMAP, DCM, $0{ }^{\circ} \mathrm{C}$ to r.t.; b) substituted acid chloride, pyridine, DCM, r. t., $3 \mathrm{~h}$. 
Table 1 - Characterization of the synthesized compounds.

\begin{tabular}{|c|c|c|c|}
\hline Compounds & ${ }^{1}$ H NMR & $\begin{array}{l}\text { m.p. } \\
\left({ }^{\circ} \mathrm{C}\right)\end{array}$ & $\begin{array}{c}\text { Yield } \\
(\%)\end{array}$ \\
\hline $\begin{array}{l}\text { 3-(4- } \\
\text { methoxybenzoyl)- } \\
\text { coumarin }(\mathbf{1})\end{array}$ & $\begin{array}{l}3.85\left(\mathrm{~s}, 3 \mathrm{H}, \mathrm{CH}_{3}\right), 7.05(\mathrm{~d}, J=8.8 \mathrm{~Hz}, 2 \mathrm{H}, \mathrm{H}-3 \\
\text { ', } \\
\mathrm{H}-5 \text { ') } 7.33-7.55(\mathrm{~m}, 2 \mathrm{H}, \mathrm{H}-6, \mathrm{H}-7), 7.70(\mathrm{~d}, J= \\
7.26 \mathrm{~Hz}, 1 \mathrm{H}, \mathrm{H}-8), 7.83(\mathrm{~d}, J=8.6 \mathrm{~Hz}, 1 \mathrm{H}, \mathrm{H}- \\
5), 7.92\left(\mathrm{~d}, J=8.8 \mathrm{~Hz}, 2 \mathrm{H}, \mathrm{H}-2^{\prime}, \mathrm{H}-6 \text { ') }, 8.34(\mathrm{~s},\right. \\
1 \mathrm{H}, \mathrm{H}-4),\end{array}$ & $174-176$ & 93 \\
\hline $\begin{array}{l}\text { 3-benzoyl-6-bromo- } \\
\text { 8-methoxy-coumarin } \\
\text { (2) }\end{array}$ & $\begin{array}{l}3.82\left(\mathrm{~s}, 3 \mathrm{H}, \mathrm{OCH}_{3}\right), 7.09 \text { (s, 1H, H-7), } 7.14 \text { (s, } \\
1 \mathrm{H}, \mathrm{H}-5), 7.24-7.51 \text { (m, 3H, H-3', H-4', H-5'), } \\
7.69(\mathrm{~d}, 2 \mathrm{H}, \mathrm{H}-2 \text { ', H-6', J= 7.3), } 7.78 \text { (s, 1H, H- } \\
\text { 4). }\end{array}$ & $207-209$ & 49 \\
\hline $\begin{array}{l}\text { 3-(3,4- } \\
\text { dimethoxybenzoyl)- } \\
\text { 8-methoxy-coumarin } \\
\text { (3) }\end{array}$ & $\begin{array}{l}3.81\left(\mathrm{~s}, 3 \mathrm{H}, \mathrm{OCH}_{3}\right), 3.85\left(\mathrm{~s}, 3 \mathrm{H}, \mathrm{OCH}_{3}\right), 3.93 \\
\left(\mathrm{~s}, 3 \mathrm{H}, \mathrm{OCH}_{3}\right), 7.04\left(\mathrm{~d}, J=8.2 \mathrm{~Hz}, 1 \mathrm{H}, \mathrm{H}-5^{\prime}\right), \\
7.27-7.43(\mathrm{~m}, 3 \mathrm{H}, \mathrm{H}-5, \mathrm{H}-6, \mathrm{H}-7), 7.46(\mathrm{~d}, J= \\
\left.2.1 \mathrm{~Hz}, 1 \mathrm{H}, \mathrm{H}-2^{\prime}\right), 7.54(\mathrm{dd}, J=8.2,2.1 \mathrm{~Hz}, 1 \mathrm{H}, \\
\left.\mathrm{H}-6^{\prime}\right), 8.28(\mathrm{~s}, 1 \mathrm{H}, \mathrm{H}-4) .\end{array}$ & $238-240$ & 95 \\
\hline $\begin{array}{l}\text { 6-bromo-3-(3,4- } \\
\text { dimethoxybenzoyl)- } \\
\text { 8-methoxy-coumarin } \\
\text { (4) } \\
\end{array}$ & $\begin{array}{l}3.80\left(\mathrm{~s}, 3 \mathrm{H}, 3^{\prime}-\mathrm{OCH}_{3}\right), 3.85\left(\mathrm{~s}, 3 \mathrm{H}, 8-\mathrm{OCH}_{3}\right), \\
3.96\left(\mathrm{~s}, 3 \mathrm{H}, 4^{\prime}-\mathrm{OCH}_{3}\right), 7.04(\mathrm{~d}, J=8.5 \mathrm{~Hz}, 1 \mathrm{H}, \\
\left.\mathrm{H}-5^{\prime}\right), 7.46\left(\mathrm{~s}, 1 \mathrm{H}, \mathrm{H}-2^{\prime}\right), 7.49-7.67(\mathrm{~m}, 3 \mathrm{H}, \mathrm{H}- \\
\left.5, \mathrm{H}-7, \mathrm{H}-6^{\prime}\right), 8.21(\mathrm{~s}, 1 \mathrm{H}, \mathrm{H}-4) .\end{array}$ & $276-277$ & 90 \\
\hline $\begin{array}{l}\text { 3-(4- } \\
\text { hidroxybenzoyl)- } \\
\text { coumarin (5) }\end{array}$ & $\begin{array}{l}6.86\left(\mathrm{~d}, J=8.8,2 \mathrm{H}, \mathrm{H}-3^{\prime}, \mathrm{H}^{\prime} 5^{\prime}\right), 7.37-7.51(\mathrm{~m}, \\
2 \mathrm{H}, \mathrm{H}-6, \quad \mathrm{H}-8), 7.64-7.78 \quad(\mathrm{~m}, 1 \mathrm{H}, \mathrm{H}-7), \\
7.75-7.89\left(\mathrm{~m}, 3 \mathrm{H}, \mathrm{H}-5, \mathrm{H}-2^{\prime}, \mathrm{H}^{\prime} 6^{\prime}\right), 8.30(\mathrm{~s}, 1 \mathrm{H}, \\
\mathrm{H}-4), 10.58(\mathrm{~s}, 1 \mathrm{H}, \mathrm{OH}) .\end{array}$ & $242-243$ & 78 \\
\hline $\begin{array}{l}\text { 3-benzoyl-6-bromo- } \\
\text { 8-hydroxy-coumarin } \\
\text { (6) }\end{array}$ & $\begin{array}{l}7.24-7.34 \text { (m, 1H, H-8), 7.44-7.63 (m, 3H, H- } \\
\left.3^{\prime}, \mathrm{H}_{-} 4^{\prime}, \mathrm{H}-5^{\prime}\right), 7.64-7.79(\mathrm{~m}, 1 \mathrm{H}, \mathrm{H}-5), 7.93 \\
\left(\mathrm{dd}, J=8.1,1.4 \mathrm{~Hz}, 2 \mathrm{H}, \mathrm{H}-2^{\prime}, \mathrm{H}-6^{\prime}\right), 8.30(\mathrm{~s}, 1 \mathrm{H}, \\
\mathrm{H}-4), 10.92(\mathrm{~s}, 1 \mathrm{H}, \mathrm{OH})\end{array}$ & 293-294 & 98 \\
\hline $\begin{array}{l}\text { 3-(3,4- } \\
\text { dihydroxybenzoyl)-8- } \\
\text { hydroxy-coumarin } \\
\text { (7) }\end{array}$ & $\begin{array}{l}6.82\left(\mathrm{~d}, J=8.2 \mathrm{~Hz}, 1 \mathrm{H}, \mathrm{H}-5^{\prime}\right), 7.06-7.36(\mathrm{~m}, \\
\left.5 \mathrm{H}, \mathrm{H}-5, \mathrm{H}-6, \mathrm{H}-7, \mathrm{H}-2^{\prime}, \mathrm{H}-6^{\prime}\right), 8.20(\mathrm{~s}, 1 \mathrm{H}, \mathrm{H}- \\
4), 9.47(\mathrm{~s}, 1 \mathrm{H}, \mathrm{OH}), 10.10(\mathrm{~s}, 1 \mathrm{H}, \mathrm{OH}), 10.35 \\
(\mathrm{~s}, 1 \mathrm{H}, \mathrm{OH})\end{array}$ & $277-278$ & 81 \\
\hline $\begin{array}{l}\text { 6-bromo-3-(3,4- } \\
\text { dihydroxybenzoyl)-8- } \\
\text { hydroxy-coumarin } \\
\text { (8) }\end{array}$ & $\begin{array}{l}6.81\left(\mathrm{dd}, J=8.1,3.0 \mathrm{~Hz}, 1 \mathrm{H}, \mathrm{H}-6^{\prime}\right), 7.12-7.38 \\
\left(\mathrm{~m}, 3 \mathrm{H}, \mathrm{H}-7, \mathrm{H}^{\prime} \mathrm{2}^{\prime}, \mathrm{H}-5^{\prime}\right), 7.45(\mathrm{~d}, J=2.2 \mathrm{~Hz}, \\
1 \mathrm{H}, \mathrm{H}-5), 8.14(\mathrm{~s}, 1 \mathrm{H}, \mathrm{H}-4), 9.48(\mathrm{~s}, 1 \mathrm{H}, \mathrm{OH}), \\
10.14(\mathrm{~s}, 1 \mathrm{H}, \mathrm{OH}), 10.89(\mathrm{~s}, 1 \mathrm{H}, \mathrm{OH}) .\end{array}$ & $300-301$ & 69 \\
\hline $\begin{array}{l}N \text {-phenyl-coumarin- } \\
\text { 3-carboxamide }(\mathbf{9})\end{array}$ & $\begin{array}{l}7.15 \text { (td, 1H, H-4', J=1.1, 7.4), 7.35-7.55 (m, } \\
\text { 4H, H-6, H-8, H-3', H-5'), 7.70-7.78 (m, 3H, } \\
\text { H-7, H-2', H-6'), } 8.00 \text { (dd, 1H, H-5, J=1.6,7.7), } \\
8.90 \text { (s, 1H, H-4), } 10.63 \text { (s, 1H, NH). }\end{array}$ & $256-257$ & 78 \\
\hline $\begin{array}{c}N-(2- \\
\text { hydroxyphenyl)- } \\
\text { coumarin-3- } \\
\text { carboxamide }(\mathbf{1 0})\end{array}$ & $\begin{array}{l}\text { 6.82-6-92 (m, 3H, H-8, H-4', H-5'), 7.46-7.57 } \\
\text { (m, 2H, H-6, H-7), } 7.76 \text { (d, 1H, H-5, J=7.4), } \\
8.04 \text { (d, 1H, H-3', J=7.1), } 8.39 \text { (d, 1H, H-6', } \\
J=7.1), 9.05(\mathrm{~s}, 1 \mathrm{H}, \mathrm{H}-4), 10.23 \text { (s, 1H, OH), }\end{array}$ & $269-270$ & 54 \\
\hline
\end{tabular}




\begin{tabular}{|c|c|c|c|}
\hline & $11.11(\mathrm{~s}, 1 \mathrm{H}, \mathrm{NH})$ & & \\
\hline $\begin{array}{l}N-(3- \\
\text { hydroxyphenyl)- } \\
\text { coumarin-3- } \\
\text { carboxamide (11) }\end{array}$ & $\begin{array}{l}6.75\left(\mathrm{~d}, 2 \mathrm{H}, \mathrm{H}-3^{\prime}, \mathrm{H}_{-} 5^{\prime} J=7.5\right), 7.41-7.58(\mathrm{~m}, \\
\left.4 \mathrm{H}, \mathrm{H}-7, \mathrm{H}-8, \mathrm{H}-2^{\prime}, \mathrm{H}^{\prime} 6^{\prime}\right), 7.76(\mathrm{t}, 1 \mathrm{H}, \mathrm{H}-6, J= \\
6.8), 8.01(\mathrm{t}, 1 \mathrm{H}, \mathrm{H}-5, J=6.8), 8.89(\mathrm{~s}, 1 \mathrm{H}, \mathrm{H}- \\
4), 9.37(\mathrm{~s}, 1 \mathrm{H}, \mathrm{OH}), 10.44(\mathrm{~s}, 1 \mathrm{H}, \mathrm{NH}) .\end{array}$ & $261-262$ & $51 \%$ \\
\hline $\begin{array}{l}\quad N-(2- \\
\text { hydroxyphenyl)-6- } \\
\text { methyl-coumarin-3- } \\
\text { carboxamide (12) }\end{array}$ & $\begin{array}{l}2.35\left(\mathrm{~s}, 3 \mathrm{H}, \mathrm{CH}_{3}\right), 6.76-6.92\left(\mathrm{~m}, 2 \mathrm{H}, \mathrm{H}-4^{\prime}, \mathrm{H}_{-}\right. \\
\left.5^{\prime}\right), 7.40\left(\mathrm{~d}, 2 \mathrm{H}, \mathrm{H}-7, \mathrm{H}-8^{\prime}, J=8.6\right), 7.55(\mathrm{~d}, 1 \mathrm{H}, \\
\left.\mathrm{H}^{-} 3^{\prime}, J=8.2\right), 7.77(\mathrm{~s}, 1 \mathrm{H}, \mathrm{H}-5), 8.35(\mathrm{~d}, 1 \mathrm{H}, \mathrm{H}- \\
6, J=7.5), 8.92(\mathrm{~s}, 1 \mathrm{H}, \mathrm{H}-4), 10.18(\mathrm{~s}, 1 \mathrm{H}, \mathrm{OH}), \\
11.08(\mathrm{~s}, 1 \mathrm{H}, \mathrm{NH}) .\end{array}$ & $274-275$ & $46 \%$ \\
\hline $\begin{array}{c}N \text {-(coumarin-3- } \\
\text { yl)benzamide }(\mathbf{1 3})\end{array}$ & Ref. [16] & - & - \\
\hline $\begin{array}{c}\text { 4-methoxy- } N \text { - } \\
\text { (coumarin-3- } \\
\text { yl)benzamide }(\mathbf{1 4})\end{array}$ & Ref. [16] & - & - \\
\hline $\begin{array}{l}\text { 3,4-dimethoxy- } N \text { - } \\
\text { (coumarin-3- } \\
\text { yl)benzamide (15) }\end{array}$ & $\begin{array}{l}3.83\left(\mathrm{~s}, 6 \mathrm{H},\left(\mathrm{OCH}_{3}\right)_{2}\right), 7.09\left(\mathrm{~d}, 1 \mathrm{H}, \mathrm{H}-5^{\prime},\right. \\
J=8.46), 7.33-7.44(\mathrm{~m}, 2 \mathrm{H}, \mathrm{H}-6, \mathrm{H}-6 \text { '), } 7.51- \\
7.61(\mathrm{~m}, 3 \mathrm{H}, \mathrm{H}-2 \text { ' }, \mathrm{H}-7, \mathrm{H}-8) 7.74(\mathrm{~d}, 1 \mathrm{H}, \mathrm{H}-5, \\
J=7.67), 8.55(\mathrm{~s}, 1 \mathrm{H}, \mathrm{H}-4), 9.51(\mathrm{~s}, 1 \mathrm{H},-\mathrm{NH}) .\end{array}$ & $187-188$ & $80 \%$ \\
\hline $\begin{array}{l}\text { 4-chloro- } N- \\
\text { (coumarin-3- } \\
\text { yl)benzamide }(\mathbf{1 6})\end{array}$ & Ref. [16] & - & - \\
\hline
\end{tabular}

\section{Pharmacology: AChE and BuChE inhibition}

In 96-well plates, the sample was dissolved in phosphate buffer $\left(8 \mathrm{mM} \mathrm{K} \mathrm{HPO}_{4}, 2.3\right.$ $\mathrm{mM} \mathrm{NaH}{ }_{2} \mathrm{PO}_{4}, 150 \mathrm{mM} \mathrm{NaCl}$, and $0.05 \%$ Tween 20 at $\mathrm{pH}$ 7.6) and an AChE/BuChE solution (50 $\mu \mathrm{L}, 0.25 \mathrm{unit} / \mathrm{mL})$ from Electroporus electricus and equine serum, respectively, in the same phosphate buffer, was added. The assay solutions, except substrate, were pre-incubated with the enzyme for $30 \mathrm{~min}$ at room temperature. After pre-incubation, the substrate was added. The substrate solution consists of $\mathrm{Na}_{2} \mathrm{HPO}_{4}(40$ $\mathrm{mM})$, acetylthiocholine/butyrylthiocholine $\quad(0.24 \mathrm{mM})$ and 5,5'-dithio-bis-(2nitrobenzoic acid) (0.2 mM, DTNB, Ellman's reagent). Absorbance of the yellow anion product, due to the spontaneous hydrolysis of substrate, was measured at $405 \mathrm{~nm}$ for 5 min on a microtiter plate reader (Multiskan EX, Thermo, Vantaa, Finland). The $\mathrm{AChE} / \mathrm{BuChE}$ inhibition was determined for each compound. The enzyme activity was calculated as a percentage compared to a control using only the buffer and enzyme solution. The compounds were assayed in the dilution interval of 500 to $15 \mu \mathrm{g} / \mathrm{mL}$, and the alkaloid galanthamine was used as the reference compound. Each assay was run in 
triplicate and each reaction was repeated at least three independent times. The $\mathrm{IC}_{50}$ values were calculated by means of regression analysis. ${ }^{[21]}$

\section{Pharmacology: MAO-A and MAO-B inhibition}

Briefly, $0.1 \mathrm{~mL}$ of sodium phosphate buffer $(0.05 \mathrm{M}, \mathrm{pH} 7.4)$ containing various concentrations of the test drugs (new compounds or reference inhibitors) and adequate amounts of recombinant $h \mathrm{MAO}-\mathrm{A}$ or $h \mathrm{MAO}-\mathrm{B}$ required and adjusted to obtain in our experimental conditions the same reaction velocity, i.e., to oxidize (in the control group) $165 \mathrm{pmol}$ of $p$-tyramine/min ( $h \mathrm{MAO}-\mathrm{A}: 1.1 \mu \mathrm{g}$ protein; specific activity: $150 \mathrm{nmol}$ of $p$ tyramine oxidized to $p$-hydroxyphenylacetaldehyde/min/mg protein; $h \mathrm{MAO}-\mathrm{B}: 7.5 \mu \mathrm{g}$ protein; specific activity: $22 \mathrm{nmol}$ of $p$-tyramine transformed $/ \mathrm{min} / \mathrm{mg}$ protein) were incubated for $15 \mathrm{~min}$ at $37{ }^{\circ} \mathrm{C}$ in a flat-black-bottom 96-well microtest plate (BD Biosciences, Franklin Lakes, NJ, USA) placed in the dark multimode microplate reader chamber. After this incubation period, the reaction was started by adding (final concentrations) $200 \mu \mathrm{M}$ Amplex Red reagent, $1 \mathrm{U} / \mathrm{mL}$ horseradish peroxidase and 1 $\mathrm{mM}$-tyramine. The production of $\mathrm{H}_{2} \mathrm{O}_{2}$ and, consequently, of resorufin was quantified at $37{ }^{\circ} \mathrm{C}$ in a multi-mode microplate reader (Fluostar Optima, BMG Labtech GmbH, Offenburg, Germany), based on the fluorescence generated (excitation, $545 \mathrm{~nm}$, emission, $590 \mathrm{~nm}$ ) over a $15 \mathrm{~min}$ period, in which the fluorescence increased linearly.

Control experiments were carried out simultaneously by replacing the test drugs (new compounds and reference inhibitors) with appropriate dilutions of the vehicles. In addition, the possible capacity of the above test drugs to modify the fluorescence generated in the reaction mixture due to non-enzymatic inhibition (e.g., for directly reacting with Amplex Red reagent) was determined by adding these drugs to solutions containing only the Amplex Red reagent in a sodium phosphate buffer.

To determine the kinetic parameters of $h \mathrm{MAO}-\mathrm{A}$ and $h \mathrm{MAO}-\mathrm{B}\left(\mathrm{K}_{\mathrm{m}}\right.$ and $\left.\mathrm{V}_{\max }\right)$, the corresponding enzymatic activity of both isoforms was evaluated (under the experimental conditions described above) in presence of a number (a wide range) of $p$ tyramine concentrations.

The specific fluorescence emission (used to obtain the final results) was calculated after subtraction of the background activity, which was determined from vials containing all components except the MAO isoforms, which were replaced by a sodium phosphate buffer solution. 


\section{Pharmacology: anti-oxidant activity}

To the corresponding coumarin-chalcone hybrid compound $(1.2 \mathrm{mmol})$ in dimethyl sulfoxide $(20 \mu \mathrm{L})$, a hydrogen peroxide solution $(50 \mu \mathrm{L}, 30 \%)$ and a sodium hydroxide solution $(50 \mu \mathrm{L}, 25 \mathrm{mM})$ were added. The total volume of the resulting solution (300 $\mu \mathrm{L}$ ) was completed with DMSO to achieve a final $4 \mathrm{mM}$ solution of the tested compounds.

The ORAC-FL assays were carried out on a Synergy HT multidetection microplate reader (Bio-Tek Instruments, Inc.) using white polystyrene 96-well plates. Fluorescence was read from the top, with an excitation wavelength of $485 / 20 \mathrm{~nm}$ and an emission filter of 528/20 nm. The plate reader was controlled by Gen 5 software. The oxygen radical absorbance capacity was determined as previously described46 with slight modifications. The reaction was carried out in $75 \mathrm{mM}$ sodium phosphate buffer ( $\mathrm{pH} 7.4$ ) at a $200 \mu \mathrm{L}$ final volume. FL (70 nM, final concentration) and coumarin-chalcone solutions in methanol with a range of concentration between 0.3 to $2 \mu \mathrm{M}$ and 0.5 to 7 $\mu \mathrm{M}$ for the monohydroxy and dihydroxy derivatives, respectively, were placed in each well of the 96-well plate. This range of concentration was selected empirically to obtain a good separation between the fluorescence curves. This separation was crucial for more accurate data treatment. The mixture was preincubated for $15 \mathrm{~min}$ at $37{ }^{\circ} \mathrm{C}$ before rapidly adding the AAPH solution (18 $\mathrm{mM}$, final concentration). The microplate was immediately placed in the reader and automatically shaken prior to each reading. The fluorescence was recorded every $1 \mathrm{~min}$ for $120 \mathrm{~min}$. A blank with FL and AAPH using methanol instead of the antioxidant solution as well as five calibration solutions using Trolox $(0.5$ to $2.5 \mu \mathrm{M})$ as a standard molecule were also used in each assay. The inhibition capacity was expressed as ORAC values, and it was quantified by employing eq 1. All reaction mixtures were prepared in triplicate, and at least three independent assays were performed for each sample.

$$
\text { relative ORAC value }=\frac{[A U C]-\left[A U C^{0}\right]}{A U C_{\text {trolox }}-A U C^{0}} \frac{[\text { trolox }]}{[\text { derivative }]}
$$

where $\mathrm{AUC}^{0}=$ area under the curve blank; $\mathrm{AUC}=$ area under the curve derivative; $\mathrm{AUC}_{\text {trolox }}=$ area under the curve, Trolox (standard); [trolox $]=$ Trolox concentration, molar; and [derivative] $=$ derivative concentration, molar.

The AUC was calculated by integrating the decay of the fluorescence where F0 is the initial fluorescence read at $0 \mathrm{~min}$ and $\mathrm{F}$ is the fluorescence read at a particular time. The 
AUCNET corresponding to the sample was calculated by subtracting the AUC corresponding to the blank. Data processing was performed using Origin Pro 8 SR2 (Origin Lab Corporation). Antioxidant Reactivity by ESR Assay. The reactivity of all coumarin-chalcone hybrids against hydroxyl radicals was assessed using the noncatalytic Fenton method that was previously described.56 In a typical experiment, $150 \mu \mathrm{L}$ of dimethyl sulfoxide was mixed with $50 \mu \mathrm{L}$ of $\mathrm{NaOH}(3 \mathrm{mM})$ followed by the addition of $50 \mu \mathrm{L}$ of DMPO (30 mM) spin trap and $50 \mu \mathrm{L}$ of hydrogen peroxide (30\%). All derivatives were studied at a $4 \mathrm{mM}$ final concentration and a $300 \mu \mathrm{L}$ final volume. The mixture was positioned in the ESR cell, and the spectra were recorded after $5 \mathrm{~min}$ of the reaction.

\section{Pharmacology: cytotoxicity and cytoprotection assays}

Cytotoxicity assays in BAEC cells were performed for all coumarin-chalcone hybrids using the MTT reduction assay. BAEC were seeded in 24-well plates at a density ranging between $104-105$ cells $/ \mathrm{mL}$ per well. After the cells reached $60-70 \%$ confluence, they were incubated in the presence of 10 to $50 \mu \mathrm{M}$ of the corresponding coumarin-chalcone derivatives for $24 \mathrm{~h}$. After incubation, the medium was changed (2 $\mathrm{mL})$ and $45 \mu \mathrm{L}$ of a solution of MTT $(5 \mathrm{mg} / \mathrm{mL}$ in DMEM supplemented with $0.5 \%$ FBS) was added to each well. The cells were incubated for another $2 \mathrm{~h}$ at $37{ }^{\circ} \mathrm{C}$. The medium was then removed, and the wells were rinsed once with PBS. DMSO (0.6 mL) was added to each well at room temperature to solubilize the formazan crystals. The dissolved formazan was then transferred into 96-well culture plates, and the absorbance was measured at $570 \mathrm{~nm}$ using a UV-vis spectrometer. The percent of inhibition of cell viability was calculated using eq 2 percent inhibition $(1 / 100)=-$ A A t s (2) where At and As are the absorbance of the sample solution and the solvent alone, respectively. To assess the cytoprotective properties of the compounds against $\mathrm{H}_{2} \mathrm{O}_{2}$ and SIN-1, BAEC (104-105 cells $/ \mathrm{mL})$ were grown to $60-70 \%$ confluence in 24 -well plates and each well was incubated with the selected derivative at 10 and $20 \mu \mathrm{M}$ concentrations for $24 \mathrm{~h}$. After incubation, the cells were washed with $1 \times$ PBS twice to remove the residual drug and exposed to $1 \mathrm{mM}$ of $\mathrm{H}_{2} \mathrm{O}_{2}$ and $500 \mu \mathrm{M}$ of SIN-1 for $2 \mathrm{~h}$ and $4 \mathrm{~h}$, respectively. These time periods were chosen on the basis of the observed cell death (>50\%) using the $\mathrm{H}_{2} \mathrm{O}_{2}$ and SIN-1 concentrations mentioned above. Finally, cell viability was evaluated by the MTT reduction assay and calculated using eq 2. Statistical Analysis. The experimental results are expressed as the mean \pm standard error of the mean (SEM) and are 
accompanied by the number ( $n$ ) of observations. The differences between the groups were analyzed by student's t test.

\section{Results and Discussion}

In the present work we exploit the synthesis and pharmacological activity of a series of coumarin derivatives (figure 1). With the aim to mimic some of the structural functions of already natural products, we explored the importance of the nature of different spacers in the position 3 of the coumarin scaffold and some small groups (methyl, methoxy, hydroxyl, bromo and chloro) attached to the benzenic ring. Our coumarin derivatives 1-16 were efficiently synthesized and characterized (Table 1). We started from the commercially available products, and obtained different derivatives in moderate to excellent yields. Our compounds were tested according the protocols previously reported, and we achieved promising results. In this paper we present some of those results (table 2, 3 and 4).

Table 2 - ORAC values and percentage of radicals scavenging for compounds 5-8 as measured by ESR spin trapping in competition with DMPO.

\begin{tabular}{ccc}
\hline Compound & ORAC-value & \% radical scavenging \\
\hline $\mathbf{5}$ & $9.2 \pm 0.4$ & 26 \\
$\mathbf{6}$ & $8.3 \pm 0.3$ & 65 \\
$\mathbf{7}$ & $8.1 \pm 0.6$ & 75 \\
$\mathbf{8}$ & $8.8 \pm 0.5$ & 100 \\
Trolox & $1.0 \pm 0.2$ & 31 \\
\hline Quercetin & $7.3 \pm 0.2$ & N.D. \\
\hline Catechin & $6.8 \pm 0.2$ & N.D. \\
\hline
\end{tabular}

N. D. - non determined. 
Table 3 - Cytotoxicity of compounds 5-8 tested at three different concentrations on BAEC. Results are expressed on percentage $(\%)$ of cell viability $(n=3)$.

\begin{tabular}{cccc}
\hline Compound & $\mathbf{1 0} \boldsymbol{\mu M}$ & $\mathbf{2 0} \boldsymbol{\mu M}$ & $\mathbf{5 0} \boldsymbol{\mu M}$ \\
\hline $\mathbf{5}$ & $76 \pm 7$ & $60 \pm 6$ & $44 \pm 5$ \\
$\mathbf{6}$ & $96 \pm 3$ & $101 \pm 1$ & $93 \pm 4$ \\
$\mathbf{7}$ & $49 \pm 2$ & $68 \pm 2$ & $63 \pm 2$ \\
$\mathbf{8}$ & $64 \pm 2$ & $23 \pm 2$ & $71 \pm 6$ \\
\hline
\end{tabular}

Table $4-\mathrm{IC}_{50}$ values for the compounds 9-16 and reference compounds on the enzymatic activity of human recombinant MAO-A, MAO-B, AChE and BuChE.

\begin{tabular}{|c|c|c|c|c|}
\hline Compound & $\begin{array}{c}\text { IC }_{50} \text { MAO-A } \\
\mu M\end{array}$ & $\begin{array}{c}\mathrm{IC}_{50} \mathrm{MAO-B} \\
\mu \mathrm{M}\end{array}$ & $\begin{array}{c}\mathrm{IC}_{50} \mathrm{AChE} \\
\mu \mathrm{M}\end{array}$ & $\begin{array}{c}\mathrm{IC}_{50} \mathrm{BuChE} \\
\mu \mathrm{M}\end{array}$ \\
\hline 9 & N.D. & N.D. & $565.93 \pm 0.01$ & N.A. \\
\hline 10 & N.D. & N.D. & $284.09 \pm 0.13$ & N.A. \\
\hline 12 & N.D. & N.D. & $666.37 \pm 0.11$ & N.A \\
\hline 13 & $>100$ & $0.76 \pm 0.05$ & N.A & N.A \\
\hline 14 & $>100$ & $30.50 \pm 2.06$ & $69.47 \pm 4.65$ & N.A \\
\hline 15 & $>100$ & $58.38 \pm 3.91$ & N.A & N.A \\
\hline 16 & $>100$ & $1.95 \pm 0.13$ & $18.71 \pm 0.84$ & N.A \\
\hline Seligiline & $68.73 \pm 4.21$ & $0.017 \pm 0.0019$ & - & - \\
\hline Eserine & - & - & $0.10 \pm 0.03$ & $0.15 \pm 0.02$ \\
\hline
\end{tabular}

N. D. - non determined, N.A. - non active. 


\section{Conclusions}

In this work, we describe the synthesis of different scaffolds of natural-hybrid compounds by employing different reactions settings. We successfully obtained 16 compounds in good to excellent yields. The electrochemical properties of the studied compounds proved to be excellent, presenting low oxidation potentials, very high ORAC values (higher than the reference compounds quercetin and catechin), and a high percentage of radical scavenging. The compounds presented low cytotoxicity for BAEC in culture, mainly compound $\mathbf{6}$ with $93 \%$ cell viability in the highest concentration tested.

With the enzymatic inhibition assays we could determine the $\mathrm{IC}_{50}$ values of our compounds and found that compound $\mathbf{1 3}$ is selective for MAO-B and has the best $\mathrm{IC}_{50}$ of all the compounds tested. However, the interesting part is that some compounds were found to have dual activity against both MAO-B and AChE, making them potential candidates to a lead compound and a more thorough future study.

\section{Acknowledgements}

André Fonseca and Maria João Matos thank Fundação para a Ciência e Tecnologia for the $\mathrm{PhD}$ grants. Saleta Vazquez-Rodriguez thanks Univeridade do Porto for her postdoctoral grant NORTE-07-0124-FEDER-000065.

\section{References}

1. Borges, F. et al. Simple coumarins and analogues in medicinal chemistry: occurrence, synthesis and biological activity. Curr. Med. Chem. 2005, 12, 887916.

2. Borges, F. et al. Simple coumarins: privileged scaffolds in medicinal chemistry. Front. Med. Chem. 2009, 4, 23-85.

3. Kabeya, L. et al. Inhibition of horseradish peroxidase catalytic activity by new 3phenylcoumarin derivatives: synthesis and structure-activity relationships. Bioorg. Med. Chem. 2007, 15, 1516-1524.

4. Belluti, F. et al. Design, synthesis and anticancer activities of stilbene-coumarin hybrid compounds: identification of novel proapoptotic agents. Bioorg. Med. Chem. 2010, 18, 3543-3550. 
5. Roussaki, M. et al. A novel synthesis of 3-aryl coumarins and evaluation of their antioxidant and lipoxygenase inhibitory activity. Bioorg. Med. Chem. Lett. 2010, 20, 3889-3892.

6. Ostrov, D.A. et al. Discovery of novel DNA gyrase inhibitors by high-throughput virtual screening. Antimicrob. Agents Chemother. 2007, 51, 3688-3698.

7. Neyts, J. et al. Structure-activity relationship of new anti-hepatitis C virus agents: heterobicycle-coumarin conjugates. J. Med. Chem. 2009, 52, 1486-1490.

8. Kostova, I. Coumarins as inhibitors of HIV reverse transcriptase. Curr. HIV Res. 2006, 4, 347-363.

9. Nielsen, S.F. et al. Antibacterial chalcones-bioisosteric replacement of the 4'hydroxy group. Bioorg. Med. Chem. 2004, 12, 3047-3054.

10. Pisani, L. et al. Discovery of a novel class of potent coumarin monoamine oxidase B inhibitors: development and biopharmacological profiling of 7-[(3chlorobenzyl)oxy]-4-[(methylamino)methyl]-2H-chromen-2-one methanesulfonate (NW-1772) as a highly potent, selective, reversible, and orally active monoamine oxidase B inhibitor. J. Med. Chem. 2009, 52, 6685-6706.

11. Matos, M.J. et al. A new series of 3-phenylcoumarins as potent and selective MAO-B inhibitors. Bioorg. Med. Chem. Lett. 2009, 19, 3268-3270.

12. Matos, M.J. et al. Synthesis and evaluation of 6-methyl-3-phenylcoumarins as potent and selective MAO-B inhibitors. Bioorg. Med. Chem. Lett. 2009, 19, 50535055 .

13. Matos, M.J. et al. Halogenated 3-phenylcoumarins as potent and selective MAOB inhibitors. Bioorg. Med. Chem. Lett. 2010, 20, 5157-5160.

14. Matos, M.J. et al. Synthesis and study of a series of 3-arylcoumarins as potent and selective monoamine oxidase B inhibitors. J. Med. Chem. 2011, 54, 7127-7137.

15. Matos, M.J. et al. New halogenated phenylcoumarins as tyrosinase inhibitors. Bioorg. Med. Chem. Lett. 2011, 21, 3342-3345.

16. Viña, D. et al. 3-Substituted coumarins as dual inhibitors of AChE and MAO for the treatment of Alzheimer's disease. Med. Chem. Commun. 2011, 3, 213-218.

17. Serra, S. et al. Hydroxycoumarins as selective MAO-B inhibitors. Bioorg. Med. Chem. Lett. 2012, 22, 258-261.

18. Chimenti, F. et al. Synthesis, molecular modeling, and selective inhibitory activity against human monoamine oxidases of 3-carboxamido-7-substituted coumarins. $J$. Med. Chem. 2009, 52, 1935-1942. 
19. Di Carlo, G. et al. Flavonoids: old and new aspects of a class of natural therapeutic drugs. Life Sci. 1999, 65, 337-353.

20. Matos, M. J. et al. MAO inhibitory activity modulation: 3-phenylcoumarins versus 3-benzoylcoumarins. Bioorg. Med. Chem. Lett. 2011, 21, 4224-4227.

21. De la Torre, P. et al. A novel class of selective acetylcholinesterase inhibitors: synthesis and evaluation of $(E)-2-($ benzo[ $[d]$ thiazol-2-yl)-3-heteroarylacrylnitriles, Molecules 2012, 17, 12072-12085. 